\author{
Mirosław Michalik*, Anna Cholewiak**, \\ Wojciech Jagiełowicz ${ }^{* *}$ \\ Uniwersytet Pedagogiczny w Krakowie
}

\title{
NIEMÓWIENIE, MILCZENIE, PRZEMILCZENIE, PAUZA, CZYLI WIELKIE NIC W TEORII I PRAKTYCE LOGOPEDYCZNEJ
}

\section{MUTISM, SELECTIVE MUTISM, STAYING SILENT, PAUSE - SERIOUS GAPS IN THE THEORY AND PRACTICE OF SPEECH THERAPY}

\author{
Słowa kluczowe: niemówienie, milczenie, przemilczenie, pauza, tempo wypowiedzi. \\ Keywords: mutism, lack of speech, pause, tempo of utterance.
}

\section{Wprowadzenie}

Przedmiotem współczesnej polskiej logopedii są biologiczne uwarunkowania rozwoju i zaburzeń mowy [Grabias, 2012, s. 57], przy czym sama mowa to „zespół czynności, jakie przy udziale języka wykonuje człowiek, poznając rzeczywistość i przekazując jej interpretację innym uczestnikom życia społecznego" [Grabias, 2001, s. 11]. W tak zarysowaną przestrzeń refleksji naukowej oraz działań praktycznych w sposób oczywisty wpisane jest zjawisko mówienia ${ }^{1}$. Dziś wiemy, iż mówienie jest biologicznie uwarunkowane - rozwija się, zmienia wraz z dorastaniem i starzeniem się człowieka, jest ściśle splecione z systemem językowym, z jednej strony podatne na zaburzenia, z drugiej umożliwia poznawanie rzeczywistości i przekazywanie jej interpretacji innym ludziom.

Na użytek rozważań podjętych w niniejszym opracowaniu, przyjmując ściśle lingwistyczna perspektywę, zakładamy za Renatą Grzegorczykową, iż mówienie jest jednostkowym aktem nadawczo-odbiorczym, w którym: „[...] nadawca, chcąc przekazać odbiorcy pewną informację, wybiera $\mathrm{z}$ kodu językowego odpowiednie słownictwo i struktury gramatyczne, uruchamia narządy mowne mające zrealizować formę wybranych jednostek językowych, w wyniku czego wysyła fale akustyczne

\footnotetext{
* Wydział Filologiczny, Zakład Neurolingwistyki, ul. Podchorążych 2, 30-084 Kraków.

** Studia doktoranckie Wydziału Filologicznego, ul. Podchorążych 2, 30-084 Kraków.

1 Stanowisko takie, lokujące w centrum zainteresowań zjawisko mówienia, bliskie jest Kaczmarkowskiemu definiowaniu logopedii jako nauki o komunikowaniu się człowieka [Kaczmarek, 1991].
} 
do ucha odbiorcy, w którego narządach odbiorczych dokonuje się recepcja dźwięku i jego interpretacja mentalna" [Grzegorczykowa, 2007, s. 14; por. także Michalik, 2013, s. 14] $]^{2}$.

Logopedia, będąc lingwistyką stosowaną, posiada dwa główne wymiary: teoretyczny, związany między innymi z kwestiami metodologicznymi, oraz praktyczny, ściśle wiążący się z rozwiązaniami metodycznymi. Ten pierwszy realizuje cel poznawczy - dostarcza wiedzy; drugi pozwala na opanowanie świata zewnętrznego i przekształcanie człowieka [por. Grucza, 1983, s. 42-43; Michalik, 2015, s. 32]. Każdy z tych dwóch aspektów może być punktem wyjścia do bardziej szczegółowych eksploracji, których wyniki są w stanie postawić przedmiot logopedii w nieco innym niż zastany świetle.

Teoretyczny punkt wyjścia. Jeśli mowa jest zespołem skomplikowanych ludzkich czynności, jakie zachodzą przy udziale języka i umożliwiają poznawanie rzeczywistości oraz jej przekaz [Grabias, 2012, s. 57], w tak ustrukturyzowaną przestrzeń, na jej planie semiotycznym, wpisuje się - nazwijmy to preliminaryjnie - pojęcie będące antonimem mówienia, zjawisko w pewnych sytuacjach nieprzeszkadzające poznawaniu rzeczywistości i zdolne jednocześnie do wyrażania określonych treści semantycznych [Rokoszowa, 1983, s. 132-135].

Praktyczny punkt wyjścia. Bardzo często pacjentami logopedów są osoby nie tyle mające problemy z mową i mówieniem, ile te, których sposób funkcjonowania wpisuje się w sferę antonimiczną wobec mówienia.

Sprowadzając teoretyczny i praktyczny punkt widzenia do jednego integralnego mianownika, proponujemy owo „zaprzeczenie, przeciwieństwo mówienia” nazwać terminem „niemówienie”. Tym samym, posługując się formą negacji popularnej definicji Grzegorczykowej, o niemówieniu myślimy, gdy: nadawca, (nie?) ${ }^{3}$ chcąc przekazać odbiorcy pewną informację, nie wybiera z kodu językowego odpowiedniego słownictwa i struktur gramatycznych, nie uruchamia narządów mownych mających zrealizować formę wybranych jednostek językowych, w wyniku czego nie wysyła fal akustycznych do ucha odbiorcy, w którego narządach odbiorczych nie dokonuje się recepcja dźwięku i jego interpretacja mentalna [por. Grzegorczykowa, 2007; Michalik, 2013]. Możemy również przyjąć, iż niemówienie to brak jednostkowego aktu nadawczo-odbiorczego mowy na skutek zaburzeń funkcji neuronalnych rozgrywających się w różnych okolicach ludzkiego układu nerwowego [Zyss, 2011; Michalik, 2013]. Stanowisko integrujące teoretyczny i praktyczny ogląd niemówienia wyrażone zostało przez Sławomira Śniatkowskiego: „Żadna forma milczenia nie eliminuje całkowicie postawy komunikatywnej: milczenie jest jedynie rezygnacją z werbalnego przekazywania informacji" [Śniatkowski, 2002, s. 11]. Z kolei integralny punkt wi-

2 Rozszerzając perspektywę oglądu w kierunku neurolingwistyki, zakładamy, iż „mówienie jest skomplikowanym procesem cząstkowych funkcji neuronalnych rozgrywających się w różnych okolicach ludzkiego mózgowia” [Zyss, 2011, s. 35].

3 Często nie można rozstrzygnąć, czy osoba niemówiąca chce (nie chce) przekazywać odbiorcy informację. Są zaburzenia komunikacji, w których brak woli pacjenta na przekazywanie komunikatów słownych (np. mutyzm, niektóre typy schizofazji), w innych, np. w anartrii, pacjenci chcą wyrażać treści myślowe [por. Michalik, 2013]. 
dzenia profilowany ontolingwistycznie pozwala przyjąć następującą taksonomię niemówienia: prelingwalne ${ }^{4}$, perilingwalne ${ }^{5}$ oraz postlingwalne ${ }^{6}$.

Tak zarysowana perspektywa interpretacyjna pozwala myśleć o dopisaniu niemówienia do indeksu zainteresowań współczesnej teorii i praktyki logopedii. Teoretyczny punkt widzenia obliguje do włączenia w zakres refleksji takich pojęć, jak: „milczenie”, „przemilczenie”, „pauza”. Praktyczna perspektywa pozwala wyodrębnić w badaniu niemówienia skalę makro (tu: niemówienie w klasyfikacjach zaburzeń mowy, refleksja nad fenomenem osoby niemówiącej) oraz skalę mikro (tu: badania niemówienia i - ewentualnie - dydaktyka akademicka w tym zakresie).

\section{Niemówienie a teoria logopedii - milczenie, przemilczenie, pauza}

Proponujemy, aby w ramach zakresu tematycznego pojęcia „niemówienie”, wchodzącego w znaczeniowe i terminologiczne relacje z teorią logopedii, służącą celom epistemicznym, umieścić takie pojęcia, jak: „milczenie”, „przemilczenie” i „pauza”7.

\subsection{Milczenie}

Słownik języka polskiego pod redakcją Mieczysława Szymczaka proponuje dwie definicje milczenia: po pierwsze jest to „niewydawanie głosu, nieodzywanie się, bezsłowna cisza”, po drugie - „niezajmowanie się jakimś zagadnieniem, niezabieranie głosu w jakiejś sprawie” [Szymczak, 1990, s. 174-175]. Bez wątpienia bliższa logopedii, szczególnie tej o nastawieniu metodyczno-praktycznym, jest konceptualizacja pierwsza, odsyłająca wprost do osób, które nie są w stanie porozumiewać się werbal-

4 Jest udziałem osób, które nie mówią na skutek wystąpienia przyczyn uniemożliwiających zdobycie umiejętności ekspresji werbalnej przed początkiem procesu nabywania mowy. $\mathrm{Na}$ pewno można włączyć do tej grupy pacjentów głuchych i głęboko niedosłyszących, niektóre osoby upośledzone intelektualnie (szczególnie w stopniu znacznym i głębokim), znaczny odsetek dzieci z autyzmem wczesnodziecięcym oraz kluczowe dla tego wystąpienia osoby z anartrią o podłożu mózgowego porażenia dziecięcego [Michalik, 2013, s. 15].

5 Dotyczy osób, które nie mówią na skutek wystąpienia przyczyn uniemożliwiających zdobycie umiejętności ekspresji werbalnej w trakcie trwania procesu nabywania mowy (1.-4./5. r.ż.). Do tej grupy zaliczają się przykładowo dzieci z niedokształceniem mowy o typie afazji, czyli takie, które częściowo nabyły kompetencję lingwistyczną z subkodem mówionym języka, ale na skutek ogniskowych, patologicznych zmian w obrębie mózgowia tę fragmentaryczną zdolność utraciły [Michalik, 2013, s. 15].

6 Obejmuje osoby, które utraciły zdolności mówienia po okresie nabywania mowy. Są to najczęściej ludzie dorośli, np. afatycy, laryngektomowani, niektórzy schizofrenicy, pacjenci ze stwardnieniem zanikowym bocznym czy tzw. zespołem zamknięcia [Michalik, 2013, s. 15-16].

7 Charakterystyka wyżej wymienionych pojęć została przedstawiona w tym fragmencie artykułu na podstawie monografii S. Śniatkowskiego pt. Milczenie i pauza w gramatyce nadawcy i odbiorcy. Ujęcie lingwoedukacyjne, Kraków 2002. Odwołania do większość autorów zawarte w tej części pracy zostały zaczerpnięte z podanej monografii. 
nie. Definicja druga lokuje się natomiast bliżej teorii komunikacji, klasycznej retoryki czy teorii dzieła literackiego.

Z kolei Jolanta Rokoszowa podaje, iż milczenie może być transcendentne, związane $\mathrm{z}$ ciszą i będące funkcją świata poznawalnego, stanowiącą neutralne, nienacechowane tło dla języka jako systemu semiotycznego, lub znaczące - pojawiające się na planie semiotycznym języka i zdolne wyrażać określone treści [Rokoszowa, 1983, s. 132-135]. Przy takiej orientacji metodologicznej bliska logopedii jako nauce związanej z semiologią wydaje się koncepcja milczenia jako subkodu znaczącego. W dyskursie logopedycznym milczenie jest bowiem zawsze nacechowane. Niemówiący pacjent jest relewantny, a nie nienacechowany, czyli żaden, a jego milczenie wchodzi w nierozerwalny związek z systemem językowym, z kompetencją językową i/lub komunikacyjną. Ta sama autorka koegzystencję milczenia i mówienia (mowy) ujmuje $\mathrm{w}$ formie pięciu dychotomii:

1) mówić/nie mówić - dotyczy formy przekazu i realizowana jest przez oznaczającą (signifiant) stronę znaku;

2) mówić/nie mówić - charakter semantyczny, odpowiada treściowej, oznaczanej (signifié) stronie znaku;

3) powiedzieć/nie powiedzieć - pragmatyczny wymiar działania i decyzji;

4) słuchać/nie słuchać - perspektywa słuchacza;

5) odpowiadać/nie odpowiadać - perspektywa odpowiadającego [Rokoszowa, 1994, s. 33-35].

Wydaje się, iż każda z alternatyw może mieć związek z logopedią. Pierwsza nakazuje zwrócenie uwagi na znakowy i gramatyczny charakter niemówienia. Druga skłania do refleksji dotyczącej (nie)możliwości wyrażania znaczeń przez osoby niemówiące. Trzecia wiąże się z kompetencją komunikacyjną osób niemówiących, czwartą z kolei łączyć można przykładowo z problemami audiogennymi, zarówno w aspekcie słuchu fizycznego (słyszenia), jak i uwagi słuchowej (słuchania). Opozycję ostatnią warto połączyć z takimi zjawiskami, jak mutyzm wybiórczy czy afonia histeryczna.

W inny sposób do kategorii milczenia dociera Izydora Dąbska. Uważa ona, iż omawiany fakt można rozpatrywać jako:

1) wyraz i środek komunikowania,

2) środek taktyczny działania,

3) symptom charakterologiczny,

4) kategorię moralną,

5) kategorię estetyczną,

6) kategorię mistyczną [Dąbska, 1963, s. 73-79].

Bez wątpienia stany i procesy wynikające z konceptualizacji pierwszej (aspekt komunikacyjny) i trzeciej (aspekt osobowościowy) mogą współtworzyć konteksty interpretacyjne i praktyczne z głównymi problemami współczesnej logopedii.

Perspektywa ściśle językoznawcza ukazuje kilka ujęć milczenia. Przykładowo: Zellig Harris, stojąc na gruncie strukturalizmu, wyróżnia tylko dwa jego typy: prewerbalne, czyli poprzedzające replikę, oraz postwerbalne, pojawiające się po wypowiedzi słownej [Harris, 1979, s. 199]. Natomiast pragmatyczna teoria milczenia Muriel Saville-Troike każe patrzeć na nie jak na akt komunikacji zawierający treść 
propozycjonalną, czyli dającą się przełożyć na wyrażenia językowe, posiadający własną siłę illokucyjną, ale poddający się interpretacji jedynie w kontekście wypowiedzi słownej. Inaczej mówiąc, jest to milczenie alternatywne - samodzielna replika wypełniająca miejsce oczekiwanej wypowiedzi słownej - wybierane przez nadawcę korzystającego z alternatywy: mówić lub milczeć [Saville-Troike, 1989, s. 146; por. także Śniatkowski, 2002, s. 11; Rokoszowa, 1983, s. 130]. Z kolei John Lyons, rozwijając teorię komunikacji, wyodrębnia milczenie informatywne, znaczące dla odbiorcy, oraz komunikatywne, znaczące dla nadawcy [Lyons, 1983, s. 36]. W obszar logopedii bez wątpienia wpisać można problematykę milczenia jako aktu mowy z treścią propozycjonalną oraz milczenia komunikatywnego charakteryzującego pacjenta, a będącego zdaniem dla terapeuty. Syntetyczną taksonomię kategorii milczenia przedstawić można w formie schematu:

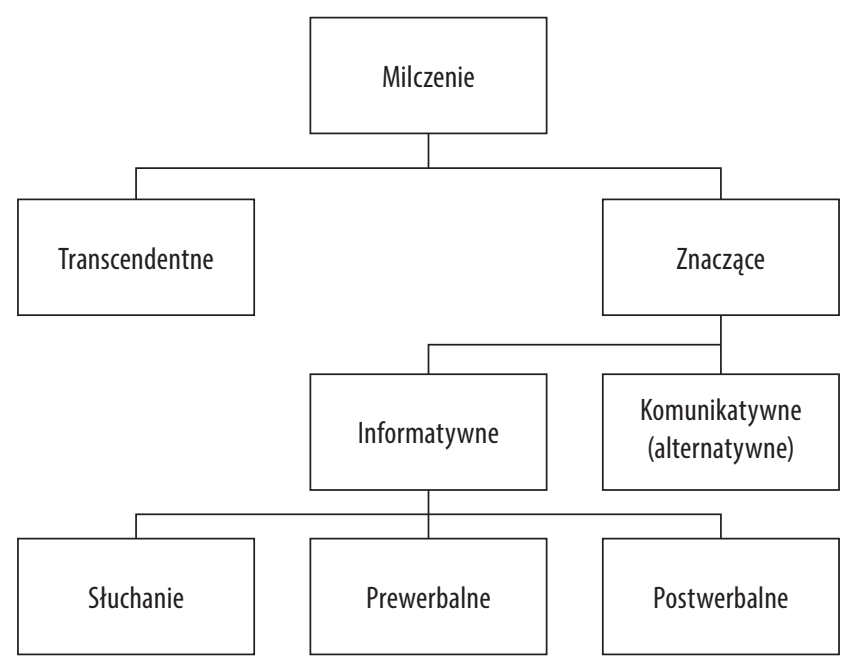

Ryc. 1. Taksonomia fenomenu milczenia z perspektywy teoretyczno-lingwistycznej

Źródło: Śniatkowski, 2002, s. 12.

\subsection{Przemilczenie}

Przemilczenie to zachowanie komunikacyjne polegające na powstrzymaniu (cenzura) lub powstrzymywaniu się (autocenzura) od komunikowania określonych treści, będące przejawem milczenia relatywnego w tekście wypowiedzi [Śniatkowski, 2002, s. 13]. Utożsamiać je można z niemówieniem o pewnych tylko sprawach [Dąbska, 1963, s. 75]. Ta jednostka komunikacji, zaliczana do podstawowych aktów mowy, pełni funkcje eliminujące (tu: unikanie „przeinformowania”, eliminacja informacji tautologicznych, redundantnych, niepożądanych, zapobieganie powstaniu tekstu lub aktu mowy przed werbalizacją, niedopowiedzenie w trakcie werbalizacji) lub stylistyczne (tu: praeteritio - deklaracja pominięcia niektórych kwestii, reticentia - nagłe przerwanie rozpoczętej myśli i zdania) [Śniatkowski, 2002, s. 13]. W dyskursie logopedycznym terapeuta 
wykorzystuje czasem przemilczenie w funkcji eliminującej. Sytuacje takie mają miejsce, gdy nadmiar informacji dostarczanych pacjentowi mógłby negatywnie oddziaływać na przebieg terapii, na przykład w sferze motywacyjnej.

\subsection{Pauza}

Zagadnieniem najgłębiej osadzonym na gruncie logopedii i jednocześnie najbardziej niejednorodnym jest pauza, czyli - zakładając wstępnie - przerwa w ciągu fonicznym, zero dźwięku w systemie znaków akustycznych, odcinek pusty w linii fali głosowej [por. Gołąb, Heinz, Polański, 1970, s. 415; Kulawik, 1994, s. 36; Polański, 1999, s. 427]. Bez wątpienia pauza pełni funkcję delimitacyjną (segmentacyjną), czyli związaną $\mathrm{z}$ aspektem składniowym, gramatycznym wypowiedzi, ponadto semantyczną i stylistyczną.

Z perspektywy formalnej pauzy analizuje się pod względem czasu ich trwania (tu: długie, czyli trwające powyżej sekundy, krótkie - poniżej sekundy ${ }^{8}$ ) oraz pod kątem postaci dźwiękowej, która stanowi ich wypełnienie (tu: właściwe, czyli niewypełnione, wypełnione, na przykład nieartykułowanymi dźwiękami, dźwiękami artykułowanymi, jednostkami leksykalnymi, oraz częściowo wypełnione, czyli będące połączeniem pauzy właściwej z wypełnioną) [Śniatkowski, 2002, s. 15-18]. Aspekty formalne pauzy przedstawiono $\mathrm{w}$ formie schematu:

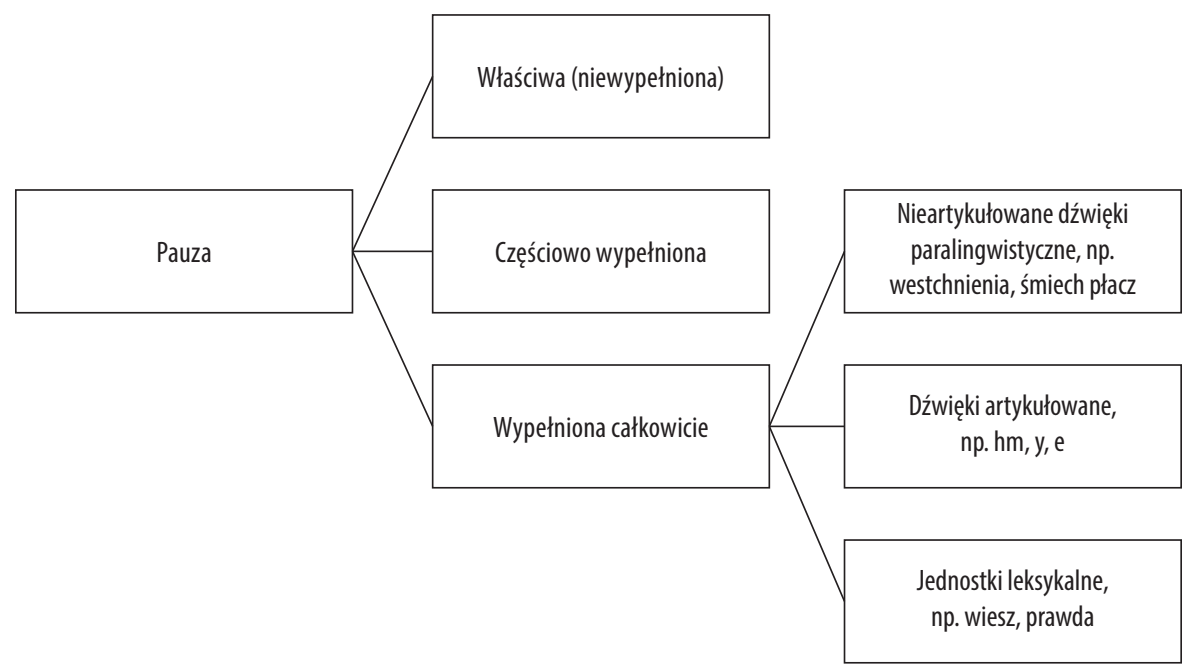

Ryc. 2. Klasyfikacja pauz z perspektywy formalnej

Źródło: Śniatkowski, 2002, s. 17.

8 Tomasz Woźniak, tworząc współczesną teorię dotyczącą zjawiska niepłynności mówienia, sugeruje, by cezurę czasową w obrębie pauz stanowił okres 2 sekund [Woźniak, 2012, s. 550]. 
Omówienie zjawiska pauzy z perspektywy funkcjonalnej warto zacząć od ryciny 3:

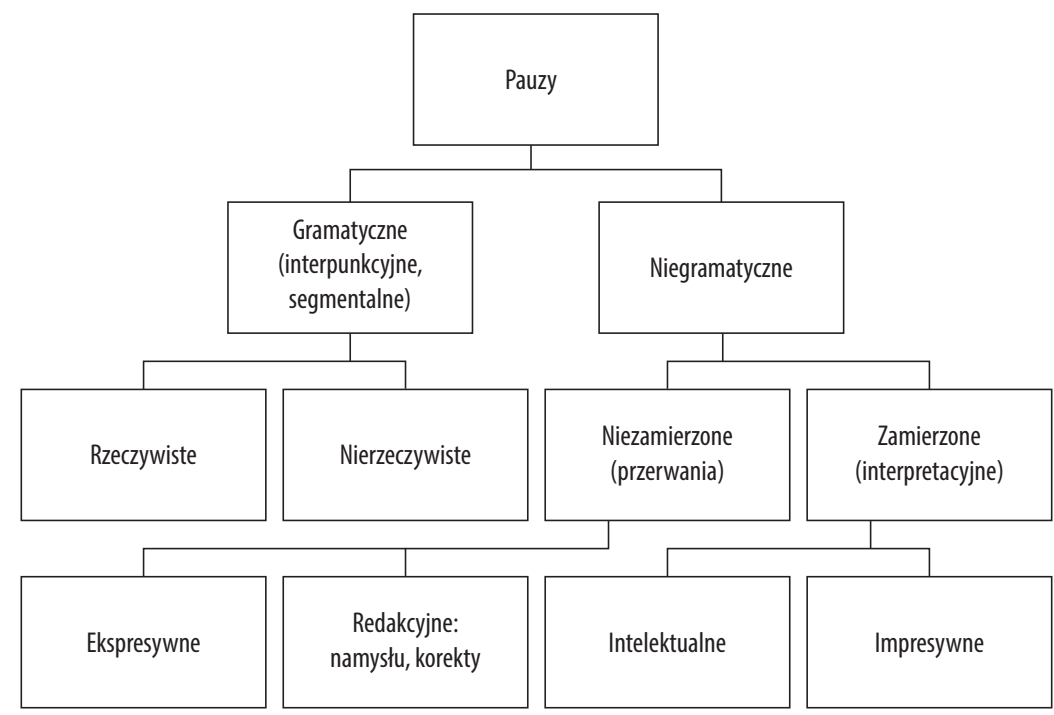

Ryc. 3. Klasyfikacja pauz z perspektywy funkcjonalnej

Źródło: Śniatkowski, 2002, s. 22.

Pauza gramatyczna to stosowana świadomie pauza, której podstawową funkcją jest zgodna ze strukturą składniową wypowiedzi segmentacja tekstu (pauza segmentacyjna, pauza delimitacyjna). Odpowiada ona znakom interpunkcyjnym w tekście pisanym (pauza interpunkcyjna). Pauza gramatyczna jest obligatoryjna z punktu widzenia poprawności gramatycznej tekstu. Pauza gramatyczna rzeczywista jest realizowana w wypowiedzi jako przerwa, pauza gramatyczna nierzeczywista jest zaś realizowana jako zmiana tonu [Śniatkowski, 2002, s. 102].

Podstawową funkcją pauzy niegramatycznej jest stylistyczne nacechowanie wypowiedzi (pauza stylistyczna). Pauza niegramatyczna może być zamierzona (pauza interpretacyjna) lub niezamierzona (pauza-przerywanie). Przy neutralnym podziale składniowym wypowiedzi pauzie niegramatycznej nie odpowiadają znaki interpunkcyjne, które jednak mogą wyrażać pauzę niegramatyczną w tekście pisanym, stylizowanym na język mówiony [Śniatkowski, 2002, s. 103]. Sama pauza interpretacyjna to świadomie stosowana w wypowiedzi pauza niegramatyczna, modyfikująca neutralny, nienacechowany charakter tekstu w celu wydobycia określonych sensów (pauza semantyczna, pauza psychologiczna) przez wydzielenie syntagm (pauza intelektualna) lub oddziaływanie na emocje odbiorcy przez nadawanie tekstowi charakteru emocjonalnego (pauza impresywna, pauza retoryczna, pauza artystyczna) [Śniatkowski, 2002, s. 102]. Z kolei pauza-przerwanie to niezamierzona i niepokrywająca się z podziałem składniowym przerwa w wypowiedzi spowodowana emocjami (pauza ekspresywna) lub będąca sygnałem aktualnego powstawania (tworzenia lub odtwarzania) tekstu (pauza namysłu lub pauza korekty) [Śniatkowski, 2002, s. 104]. 


\subsection{Pauza a tempo wypowiedzi}

W przestrzeni wspólnej lingwistyki i logopedii lokuje się zjawisko pauzy jako wyznacznika (nie)płynnego mówienia. Płynnością mówienia - za Tomaszem Woźniakiem - „nazwijmy bezproblemowe budowanie ciągu fonicznego, zrozumiałego dla odbiorcy. Płynność polega na ciągłości realizacji następujących po sobie dźwięków mowy, które występują w obrębie regularnie powtarzających się grup rytmicznych (fraz), trwających około 2-3 sekund, niemalże identycznie uporządkowanych pod względem prozodycznym. Fraza może być wypełniona różną liczbą głosek (sylab), w zależności od tempa mówienia, przy czym średnie tempo mówienia wynosi w mowie potocznej 10-12 głosek (4-5 sylab) na sekundę. Pomiędzy frazami występuje krótka pauza, której czas trwania nie jest ściśle określony. W przypadku nieprzerwanej wypowiedzi powinna być jednak krótsza niż 2 sekundy, nie ma bowiem wtedy wartości znaczącej” [Woźniak, 2012, s. 550]9 .

Z przytoczonej definicji wynika wprost, iż pauzy, czyli przerwy w ciągu fonicznym, zero dźwięku w systemie znaków akustycznych, odcinek pusty w linii fali głosowej, znajdują się poza frazami - grupami rytmicznymi. Tym samym badania długości i frekwencji pauz w ciągu wypowiedzeniowym użytkowników języka nie powinny być określane jako tempo mówienia, gdyż to ostatnie odpowiada w znaczeniu ścisłym wyłącznie liczbie jednostek ciągu mowy (głosek lub sylab) w jednostce czasu. Lepiej w takim przypadku używać szerszego znaczeniowo terminu „tempo wypowiedzi”, obejmującego zarówno jednostki znajdujące się we frazach (głoski lub sylaby), jak również pauzy. Przy czym wypowiedź, za Kazimierzem Polańskim, rozumiemy jako konkretne zdanie/wypowiedzenie wypowiadane przez użytkownika języka, odpowiadające angielskiemu „utterance” [Polański, 1999, s. 645].

Analiza stosowania pauz (ich rodzaju, czasu trwania, przyczyn, celu, intencji itd.) jest ważnym aspektem analizy wypowiedzi, pojętej jako rezultat całego aktu komunikacyjnego, dyskursu, a nie samego mówienia, które zawężamy tu do czynności narządów mowy związanych z artykulacją dźwięków. Taka perspektywa może być ważną kategorią w badaniach nad interakcją. Wykracza przy tym daleko poza zagadnienie fonetyczne.

Reasumując: tempo mówienia informuje nas o liczbie wypowiadanych głosek/sylab we frazie wypowiedzeniowej i w jednostce czasu, tempo wypowiedzi z kolei obliguje do dodania do wcześniejszych danych również formalnej (czas trwania i stopień wypełnienia) charakterystyki pauz znajdujących się poza frazami - grupami rytmicznymi, ale współtworzącymi wraz z głoskami/sylabami konkretną wypowiedźn 10 .

9 Na zasadzie przeciwwagi i uzupełnienia warto zacytować definicję niepłynności mówienia tego samego badacza: „Niepłynnością mówienia określmy zaburzenie ciągłości wymawianiowej i rytmiczności fraz. Oznacza to przerwanie ciągłości realizacji fonicznej wypowiedzi, w ramach następujących po sobie grup rytmicznych i zaburzenie regularnego następstwa czasowego tych grup (fraz). W zależności od rodzaju objawów i ich nasilenia możemy kwalifikować niepłynność mówienia jako normalną i patologiczną" [Woźniak, 2012, s. 551].

10 Za zwrócenie uwagi na tę różnicę dziękujemy Panu Profesorowi Tomaszowi Woźniakowi. 


\section{Niemówienie w praktyce logopedycznej - między skalą makro a mikro}

Praktyka logopedyczna, czyli wdrażanie prognostycznych i diagnostycznych procedur postępowania logopedycznego [por. Grabias, 2001, s. 39; 2012, s. 59-60], pozwala na rozpatrywanie zjawiska niemówienia w dwóch komplementarnych w stosunku do siebie wymiarach. Pierwszy, nazwany przez nas roboczo wymiarem makro, jest oglądem zjawiska odwołującym się do rudymentarnych problemów współczesnej logopedii. To swoista procedura interpretacyjna zjawiska niemówienia, odpowiadająca poznawczej postawie holistycznej, zapewniającej realizację celów poznawczych. Wymiar drugi, nazwany wymiarem mikro, jest próbą selektywnego, ale i aplikacyjnego docierania do wybranych faktów wiążących się z niemówieniem. To strategie interpretacyjne zjawiska, odpowiadające poznawczej postawie analitycznej, zapewniającej realizację celów praktycznych. Konkretne treści wpisujące się w wyznaczone wymiary interpretacyjne ujęto w formie schematu:

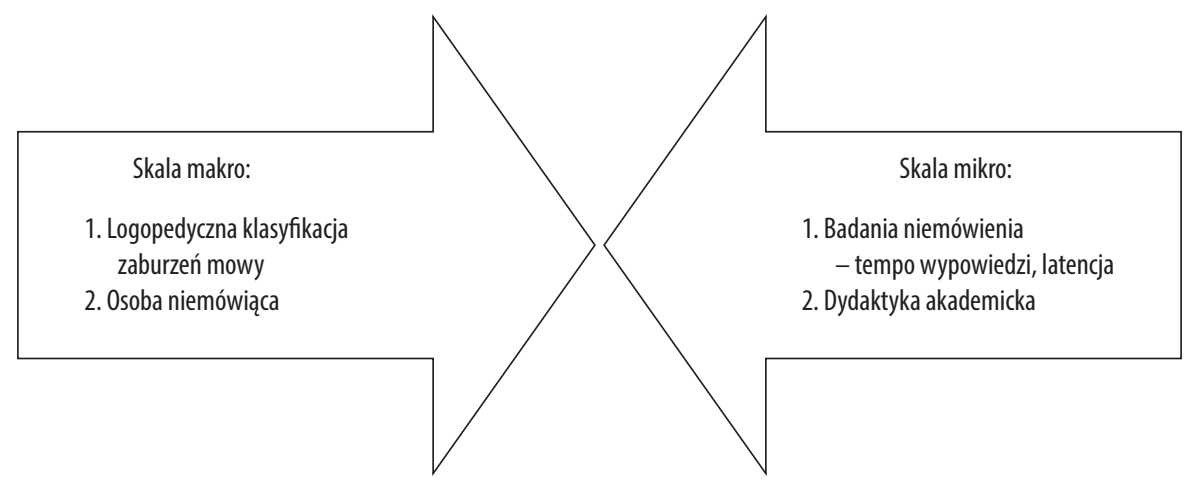

Ryc. 4. Wybrane obszary badawcze niemówienia w logopedii

Źródło: opracowanie własne.

\subsection{Niemówienie w typologii zaburzeń mowy Stanisława Grabiasa}

Logopedyczna klasyfikacja zaburzeń komunikacji językowej (typologia zaburzeń mowy) w sposób systemowy integrująca takie pojęcia, jak: „kompetencje”, „sprawności”, „procedury postępowania logopedycznego”, „strategie postępowania logopedycznego", wyznacza od przynajmniej kilkunastu lat kierunki praktycznych działań logopedycznych w zakresie programowania terapii i jej wdrażania, przyjmujące status uznanych praktycznie w całej Polsce standardów postępowania [por. np. Grabias, $1997 ; 2001 ; 2012]^{11}$.

11 Z informacji autorów, uzyskanych dzięki naukowym zagranicznym kontaktom i stażom, wynika, iż standardy postępowania logopedycznego z opracowanej przez Grabiasa typologii zaburzeń mowy są obligatoryjnie stosowane nie tylko przez logopedów w naszym kraju. Przykładowo, terapeuci mowy skupieni wokół Rady Polonii Belgijskiej, Specjalistyczne- 
W praktyce logopedycznej niemówienie jest zwykle kojarzone z mutyzmem lub ze wzbudzającą kontrowersje terminologiczne i taksonomiczne anartrią [por. Skoczek, 2014; Michalik, 2012]. Jednak traktowanie niemówienia jako pojęcia zakresowo szerokiego, czyli obejmującego takie fakty lingwistyczne, jak milczenie, pauzę, pozwala wiązać z nim więcej zjawisk logopedycznych. W uproszczonej, zaprezentowanej poniżej wersji logopedycznej typologii zaburzeń mowy czcionką pogrubioną wyróżniono te fakty logopedyczne, które obligatoryjnie powinny być łączone z niemówieniem, czcionką pochyloną - te, które z niemówieniem wiążą się po spełnieniu określonych warunków, na przykład związanych z czasem jego trwania lub stopniem wywołującego go zaburzenia rozwojowego.

I. Zaburzenia mowy związane z niewykształconymi sprawnościami percepcyjnymi: głuchota i niedostuch, oligofazja, alalia, dyslalia, autyzm, padaczki dziecięce.

II. Zaburzenia mowy związane $\mathrm{z}$ brakiem lub niedowładem sprawności realizacyjnych: dysglosja, jąkanie, giełkot, mowa bezkrtaniowa, dyzartria/anartria.

III. Zaburzenia mowy związane z rozpadem systemu komunikacyjnego: afazja, pragnozja, schizofazja, demencja.

Z przedstawionej propozycji wynika, że niemówienie zawsze towarzyszy głuchocie, mowie bezkrtaniowej, anartrii. Z kolei często należy je łączyć z niedosłuchem, oligofazją, autyzmem, epilepsją dziecięcą, dysglosją, jąkaniem, dyzartrią, afazją, schizofazją i demencją. Jedynie w przypadku dyslalii, giełkotu oraz pragnozji nie zachodzi potrzeba uwzględniania poruszonej problematyki w programowaniu i realizowaniu działań terapeutycznych.

\subsection{Osoba niemówiąca}

Logopedyczna interpretacja fenomenu osób niemówiących musi być wielofasetowa. Proponujemy odwołania do perspektywy etiologiczno-objawowej, praktyczno-terapeutycznej, lingwistycznej oraz ontologicznej.

Uwzględnienie samego kryterium etiologiczno-objawowego często musi skłaniać do włączania jakiegoś typu niemówienia w spektrum nieprawidłowości przyczynowo-symptomatologicznie związanych z omawianym problemem. Przykładem może być tutaj celowość tego typu działań, uwzględniających - podkreślamy raz jeszcze - wyłącznie etiologię i objawy w terminologicznym postrzeganiu dyzartrii i anartrii. Różnica między anartrią a dyzartrią jest rzeczywiście z tego punktu widzenia ilościowa, nie jakościowa [por. Michalik, 2012, s. 385-389, 403].

Z kolei przyjęcie perspektywy praktyczno-terapeutycznej zmusza do refleksji i pytań o sens odrębnego bądź zunifikowanego traktowania pacjenta niemówiącego

go Gabinetu Logopedycznego „Bilingual Kids”, Polskiego Centrum Kształcenia im. Jana Pawła II w Brukseli, Punktu Informacyjno-Konsultacyjnego w Brukseli, Punktu Informacyjno-Konsultacyjnego w Antwerpii, Szkolnego Punktu Konsultacyjnego im. Generała Stanisława Maczka przy Ambasadzie RP w Brukseli z siedzibą w Antwerpii, Szkolnego Punktu Konsultacyjnego im. Joachima Lelewela przy Ambasadzie RP w Brukseli, Cosmopollite Village w Paryżu, Wydziału Zamiejscowego w Dublinie Staropolskiej Szkoły Wyższej w Kielcach oraz szkół specjalnych Lwowa, Charkowa i Kijowa, organizując swoje działania logopedyczne, odwołują się do omawianej propozycji. 
i pacjenta źle mówiącego. Rozpatrzenie w kontekście niemówienia argumentów neuropsychologicznych (odmienne, prawopółkulowe przetwarzanie materiału językowego), terapeutycznych (inny dobór strategii postępowania logopedycznego dla osób niemówiących) oraz psychologicznych (często tragiczna świadomość własnego kalectwa) musi skłaniać do traktowania pacjenta niemówiącego inaczej niż pacjenta wykorzystującego subkod mówiony [Michalik, 2012, s. 389-391, 403].

Posłużenie się z kolei argumentami lingwistycznymi stawia problem różnicowej diagnozy mówienia i niemówienia w jeszcze innym świetle. Jeśli język postrzegamy jako działanie (energeia), a nie dzieło (ergon), i jako proces, nie wytwór, wówczas jego brak niesie ze sobą daleko głębsze konsekwencje, niż w przypadku patrzenia na niego tylko w kategoriach zjawiska statycznego. Osoby niemówiące posługują się najczęściej zupełnie innymi, alternatywnymi systemami komunikowania się (AAC) w stosunku do języka naturalnego. Żadna z alternatywnych metod porozumiewania się nie spełnia cech definicyjnych języków etnicznych; nie posiada także większości cech podstawowych i drugorzędnych charakteryzujących języki naturalne oraz nie można im przyporządkować wielu adekwatnych dla nich funkcji. Pozajęzykowe sposoby porozumiewania się nie są ponadto oparte na uniwersaliach językowych, dlatego ich użytkownikom niedostępna jest w pełnym wymiarze relacja język-myślenie i język-rzeczywistość [Michalik, 2012, s. 391-400, 403-404].

Ostatnia, filozoficzna płaszczyzna porównania dwóch zjawisk obnaża odrębność egzystencjalnego fenomenu osób niemówiących w stosunku do pozostałych ludzi. Niemówienie jest autonomicznym, ontologicznym i epistemicznym stanem. Stan ten wynika między innymi ze skrajnej subiektywności procesów myślowych będących udziałem osób niemówiących - subiektywności, której źródła leżą w głębokich zaburzeniach komunikacji językowej i zdolności interakcyjnych. Jak twierdzi Maurice Merleau-Ponty: „Mowa pociąga nas ku myśli, która nie należy już wyłącznie do nas, która presumptywnie nabiera charakteru powszechnego" [Merleau-Ponty, 1976, s. 32]. W podobnym tonie pisał o tym także Stanisław Grabias [2007, s. 355], twierdząc, iż język obiektywizuje poznanie rzeczywistości. Brak języka skazuje zatem ludzi na subiektywizm doznań mentalnych [Michalik, 2012, s. 400-403].

Fenomen osoby niemówiącej oraz organizacja prognostycznych procedur postępowania logopedycznego uwzględniających expressis verbis zjawisko niemówienia to najważniejsze problemy logopedii otwierającej się na omawiane zjawisko. Z kolei badanie tempa wypowiedzi, współdeterminowanego pauzą, czyli chwilowym niemówieniem, oraz akademickie kształcenie kompetencji logopedów w zakresie niwelowania skutków niemówienia, to problemy szczegółowe.

\subsection{Tempo wypowiedzi - badania wstępne}

W 2015 roku w Zakładzie Neurolingwistyki Uniwersytetu Pedagogicznego w Krakowie, między innymi w ramach badań doktorskich, rozpoczęte zostały wstępne analizy mające na celu ustalenie norm tempa wypowiedzi w dyskursach szkolnym i medialnym. W dyskursie szkolnym ocenie poddana zostaje latencja pierwszej wypowiedzi osoby badanej, szczegółowa analiza wypowiedzi obejmuje natomiast pewne 
jej parametry ilościowe ${ }^{12}$. Analizy nagrań zawierają również dokładną charakterystykę przerw w ciągu fonicznym [Gołąb, Heinz, Polański, 1970, s. 415]. Wskazujemy więc wszelkie formalne aspekty pauz (czas ich trwania oraz postać dźwiękową) [Śniatkowski, 2002, s. 15-18]. W dyskursie medialnym, podobnie jak w szkolnym, badana jest latencja rozpoczęcia wypowiedzi przez uczestników dialogu, a także przeprowadzana jest analiza tempa mówienia oraz stosowanych przez rozmówców pauz (z uwzględnieniem ich długości i formy dźwiękowej).

Badania nad dyskursem szkolnym. Analizie poddane zostają wypowiedzi uczniów w wieku 8-16 lat, uczęszczających do szkoły masowej. Każdorazowo oceniane są fragmenty nagranych wypowiedzi uczniów trwające 30 sekund. Rycina 5 przedstawia widmo przykładowego fragmentu wypowiedzi ucznia, który został poddany ocenie.

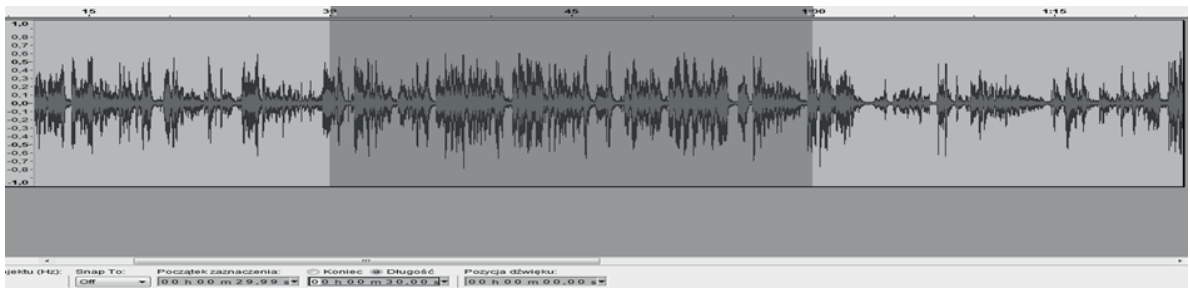

Ryc. 5. Przykładowe widmo wypowiedzi ucznia (zaznaczono fragment poddany analizie)

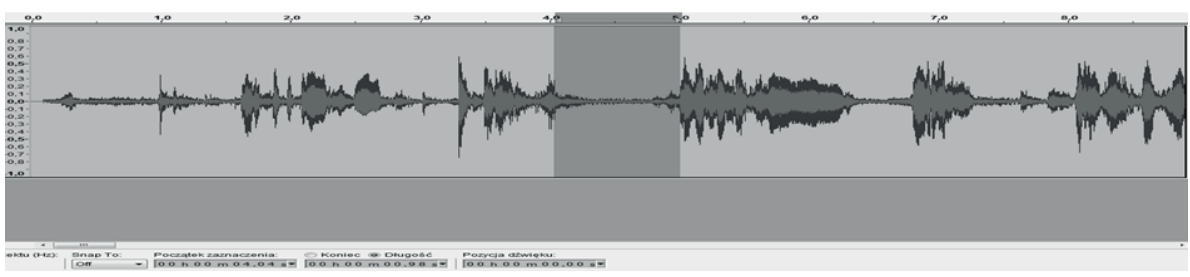

Ryc. 6. Ocena latencji pierwszej wypowiedzi ucznia

Ocenę latencji pierwszej wypowiedzi ucznia ukazuje rycina 6. Z widma nagranej wypowiedzi ucznia wynika, że czas oczekiwania na jego odpowiedź to 0,98 sekundy.

W prezentowanej przykładowej analizie wypowiedzi ucznia obliczono czas trwania wszystkich pauz, które stanowią w sumie 35,3\% badanego fragmentu wypowiedzi (10,59 sekundy). Wśród pauz wskazać można zarówno pauzy właściwe, jak i wypełnione oraz częściowo wypełnione.

W najbliższej perspektywie prowadzone dziś analizy wypowiedzi uczniów szkoły masowej porównane zostaną z analizami wypowiedzi uczniów szkół specjalnych.

Badania nad dyskursem medialnym. Analizy obejmują wypowiedzi osób występujących w programach informacyjnych i publicystycznych nadawanych przez różne stacje telewizyjne. Badane fragmenty pochodzą z programów emitowanych na żywo. Ocenie poddane są wypowiedzi prymarnie mówione spontaniczne, których

$12 \mathrm{~W}$ badaniach pilotażowych były to między innymi liczba pauz, czas ich trwania, liczba słów i sylab w określonej jednostce czasu. 
czas trwania wynosi przynajmniej 30 sekund. Na rycinie 7 ukazano widmo przykładowej analizowanej wypowiedzi.

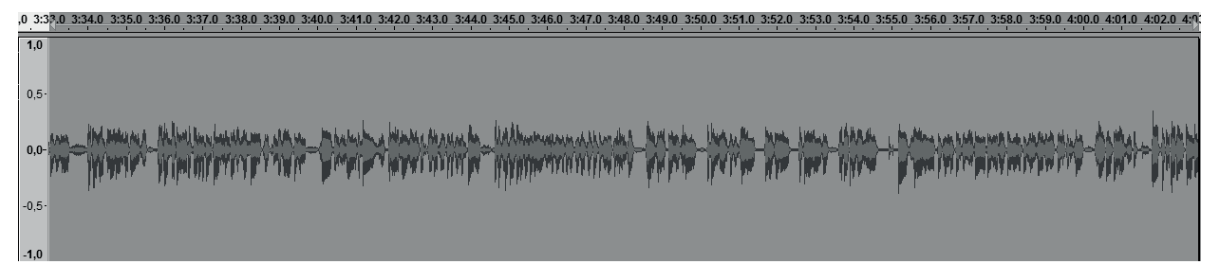

Ryc. 7. Widmo trzydziestosekundowej wypowiedzi w dyskursie medialnym

Po powiększeniu widma możliwe było obliczenie czasu trwania pauz w danym fragmencie, który wyniósł 10,65 sekundy, co stanowi $35,5 \%$ wypowiedzi, a także wskazanie latencji pierwszej wypowiedzi (ryc. 8), która wyniosła 0,51 sekundy.

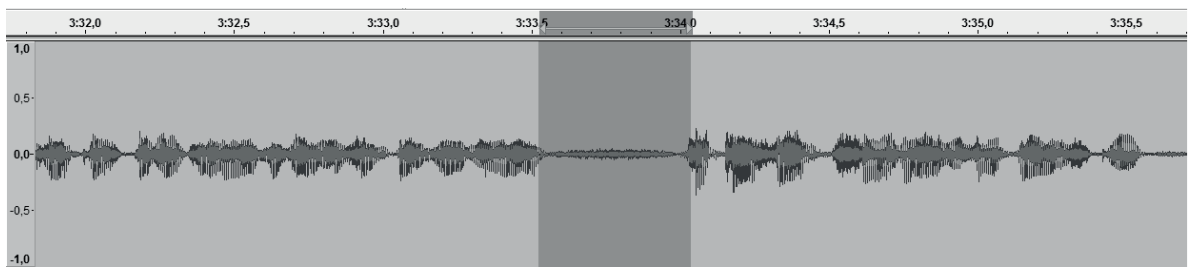

Ryc. 8. Ocena latencji pierwszej wypowiedzi uczestnika dyskursu medialnego

Prowadzone badania mają na celu wskazanie norm tempa wypowiedzi w określonym dyskursie - będzie to możliwe po dodaniu wartości charakteryzujących pauzy w wypowiedziach do danych, które pozwalają ocenić tempo mówienia.

\subsection{Dydaktyka akademicka w zakresie niemówienia}

Autorytarnie stwierdzamy, iż logopedzi są słabo przygotowywani do diagnozowania osób niemówiących, programowania terapii niemówienia i wdrażania jej. Część ośrodków uniwersyteckich w programach studiów nie posiada nawet przedmiotu, który zapoznawałby przyszłych logopedów z alternatywnymi metodami komunikacji. Najczęściej metody te traktuje się jako opozycyjne w stosunku do proponowanych w ramach tak zwanej klasycznej logopedii.

W 2014 roku Zakład Neurolingwistyki Uniwersytetu Pedagogicznego w Krakowie rozpoczął kształcenie podyplomowe w ramach trzysemestralnych studiów Porozumiewanie się osób niemówiących w praktyce terapeutycznej-alternatywne metody komunikacji. Wydaje się, iż to pierwsza w Polsce tak szeroka formuła zdobywania kompetencji terapeutycznych w zakresie niemówienia. Treści kształcenia ujęto w trzy bloki tematyczne:

1) neurolingwistyczny, obejmujący takie przedmioty, jak: wprowadzenie do neurolingwistyki, niemówienie jako zjawisko lingwistyczne, neurolingwistyka w praktyce terapeutycznej, logopedyczne podstawy diagnozy i terapii osób niemówiących; 
2) medyczny, w skład którego wchodzą przedmioty: medyczne determinanty niemówienia, niemówienie w praktyce medycznej;

3) metodyczny, w ramach którego student zdobywa umiejętności w zakresie takich przedmiotów, jak: filozoficzne i psychologiczne podstawy alternatywnych metod komunikacji, diagnoza funkcjonalna pacjenta, technologia wspomagająca komunikowanie się, metodyka postępowania terapeutycznego, alternatywne metody komunikowania się we wczesnym wspomaganiu rozwoju dziecka, alternatywne metody komunikowania się w procesie edukacji przedszkolnej i szkolnej, alternatywne metody komunikowania się osób ze spektrum autyzmu, alternatywne metody komunikowania się pacjentów z niepełnosprawnością nabytą.

Wierzymy, iż - oprócz celów praktycznych - zaprezentowana forma kształcenia przyczyni się do lepszego poznania zjawiska niemówienia.

\section{Zakończenie}

Zaprezentowane w artykule obszary refleksji naukowej i praktyki terapeutycznej stanowią punkt wyjścia, z którego warto podążać w kierunku wyodrębnienia interdyscyplinarnej (transdyscyplinarnej) nauki o niemówieniu. Mogłaby ona realizować zarówno cele poznawcze, przyczyniając się do zgłębiania fenomenu, jakim jest niemówienie, jak i praktyczne, służąc pomocą w organizowaniu działań diagnostycznych i terapeutycznych zwróconych w kierunku osób niemówiących. Ponadto, co nie bez znaczenia dla tradycji uniwersyteckich, nie musiałyby być jej obce cele transferencyjne, jakie stawia się poszczególnym specjalnościom czy dyscyplinom naukowym. Jeśli miałby być spełniony choć jeden z celów, należy o niemówieniu mówić.

Bibliografia

Dąbska Izydora, 1963, Milczenie jako wyraz i jako wartość, „Roczniki Filozoficzne”, 1, XI, s. 73-79.

Gołąb Zbigniew, Heinz Adam, Polański Kazimierz, 1970, Słownik terminologii językoznawczej, Warszawa.

Grabias Stanisław, 1997, Mowa i jej zaburzenia, „Audiofonologia”, X, s. 3-20.

Grabias Stanisław, 2001, Perspektywy opisu zaburzeń mowy, w: tenże (red.), Zaburzenia mowy, Lublin, s. 11-43.

Grabias Stanisław, 2007, Język, poznanie, interakcja, w: Tomasz Woźniak, Aneta Domagała (red.), Język, interakcja, zaburzenia mowy. Metodologia badań, Lublin, s. 355-377.

Grabias Stanisław, 2012, O ostrość refleksji naukowej. Przedmiot logopedii i procedury logopedycznego postępowania, w: Stanisław Milewski, Katarzyna Kaczorowska-Bray (red), Logopedia. Wybrane aspekty historii, teorii i praktyki, Gdańsk, s. 56-69.

Grucza Franciszek, 1983, Zagadnienia metalingwistyki. Lingwistyka - jej przedmiot, lingwistyka stosowana, Warszawa.

Grzegorczykowa Renata, 2007, Wstęp do językoznawstwa, Warszawa. 
Harris Zellig, 1979, Założenia metodologiczne językoznawstwa strukturalnego, w: Halina Kurkowska, Adam Weinsberg (red.), Językoznawstwo strukturalne, Warszawa, s. 158-174.

Kaczmarek Leon, 1991, O polskiej logopedii, w: Helena Borowiec (red.), Przedmiot logopedii, Lublin, s. 5-25.

Kulawik Adam, 1994, Poetyka. Wstęp do teorii dzieła literackiego, Kraków.

Lyons John, 1983, Semantyka 1, Warszawa.

Merleau-Ponty Maurice, 1976, Proza świata. Eseje o mowie, Warszawa.

Michalik Mirosław, 2012, Dyzartria i anartria w kontekście wieloaspektowej diagnozy różnicowej, w: Mirosław Michalik, Anna Siudak, Zdzisława Orłowska-Popek (red.) Nowa logopedia, t. 3: Diagnoza różnicowa zaburzeń komunikacji językowej, Kraków, s. 383-406.

Michalik Mirosław, 2013, Niemówienie jako problem lingwistyczny, kulturowy i szkolny. Uwagi neurolingwisty, w: Mirosław Michalik, Anna Hetman (red.), Synergia. Mowa - Terapia - Wychowanie, Jastrzębie-Zdrój-Kraków, s. 9-19.

Michalik Mirosław, 2015, Transdyscyplinarność logopedii - między metodologiczna koniecznościa a teoretyczna utopia, w: Stanisław Milewski, Katarzyna Kaczorowska-Bray (red.), Metodologia badań logopedycznych z perspektywy teorii i praktyki, Gdańsk, s. 32-46.

Polański Kazimierz (red.), 1999, Encyklopedia językoznawstwa ogólnego,

Wrocław-Warszawa-Kraków.

Rokoszowa Jolanta, 1983, Język a milczenie, „Biuletyn Polskiego Towarzystwa Językoznawczego", XL, s. 129-137.

Rokoszowa Jolanta, 1994, Milczenie jako fakt językowy, „Biuletyn Polskiego Towarzystwa Językoznawczego", L, s. 27-47.

Saville-Troike Muriel, 1989, The ethnography of communications. An introduction, Oxford. Skoczek Anna, 2014, Mutyzm - zagadnienia teorii i praktyki, Kraków.

Szymczak Mieczysław (red.), 1990, Słownik języka polskiego, t. 2, Warszawa.

Śniatkowski Sławomir, 2002, Milczenie i pauza w gramatyce nadawcy i odbiorcy.

Ujęcie lingwoedukacyjne, Kraków.

Woźniak Tomasz, 2012, Niepłynność mówienia, w: Stanisław Grabias, Marek Kurkowski (red.), Logopedia. Teoria zaburzeń mowy, Lublin, s. 549-565.

Zyss Tomasz, 2011, Neurofizjologiczne podłoże procesu mówienia - rola somatosensorycznej

kontroli zakrętów zaśrodkowych, w: Mirosław Michalik (red.), Biologiczne uwarunkowania rozwoju i zaburzeń mowy, Kraków, s. 35-55.

Summary

The article discusses the importance of the scientific description of mutism. The paper starts with linguistic arguments and talks about the phenomenon from the perspective of speech disorders typology and from the perspective of the mute person himself/herself. It suggests that the tempo of utterance (which is different from the tempo of speech) should be included in the study of mutism. It also discusses the competence of speech therapists to diagnose and program the therapy of mute people. The conclusion of the article is that the interdisciplinary research of mutism would allow for better understanding of this phenomena and a more effective therapy. 